\title{
GAS EXCHANGE IN 'POME' BANANA PLANTS GROWN UNDER DIFFERENT IRRIGATION SYSTEMS
}

\author{
Alessandro de M. Arantes ${ }^{1 *}$, Sérgio L. R. Donato ${ }^{2}$, Dalmo L. de Siqueira ${ }^{3}$, Eugênio F. Coelho ${ }^{4}$ \\ ${ }^{1 *}$ Corresponding author. Federal Institute Baiano/ Guanambi - BA, Brazil. E-mail: alessandro.arantes @ifbaiano.edu.br
}

\section{KEYWORDS}

Musa spp, AAB and AAAB genotypes, physiology.

\begin{abstract}
This study aimed to evaluate Pome type bananas grown under different irrigation systems. Seventy-two treatments were used in a factorial $3 \times 2 \times 12$ scheme, where factors consisted of three irrigation systems (under-tree sprinkling, micro-sprinkling, and dripping), two cultivars ('Prata-Anã' and 'BRS Platina'), and twelve evaluation periods (months). The treatments were arranged in a completely randomized design with five repetitions. During the third production cycle, plant phytotechnical and physiological traits were evaluated in different months at five different times of the day. The results showed no significant interactions between cultivars and irrigation systems. All the assessed traits varied for each irrigation system, except for plant yield. The banana plants presented higher vigor and a larger number of hands when grown under conventional sprinkling and microaspersion systems, regardless of the cultivar. The cultivar 'Prata-Anã' has larger leaf areas and number of hands, regardless of the irrigation system. Moreover, plants irrigated by dripping exhibited higher leaf temperatures, higher transpiration rates, and lower instant water-use efficiency. When irrigated by micro-sprinklers, the plants displayed greater water-use efficiency. As leaf temperature rose, perspiration increased linearly, while the instant water-use efficiency decreased linearly.
\end{abstract}

\section{INTRODUCTION}

Banana cultivation in areas under water scarcity requires a most rational use of this resource. An irrigation system is chosen based on the quantity and quality of available water, soil type, relief, climate, and other factors. Localized irrigation systems are more efficient; however, few studies have been carried out about its effects on plant physiological processes. The water sprayed onto the plant leaves and pseudostems may improve plant cooling and, therefore, better conditions for plant development under stressful thermal conditions. Leaf temperature variations reflect the heat transfers between plant and the environment, which directly interferes with plant physiological processes, affecting final yield (Taiz \& Zeiger, 2013).

In the recent years, several studies have investigated the gas exchanges in banana plants, but generally under controlled conditions. The response of plant physiological variables have been assessed under different conditions such as salinity levels (Silva Junior et al., 2012), nutrient rates in solutions (Neves et al., 2002; Melo et al., 2010), soil water deficit (Mahouachi, 2009), natural shading (Senevirathna et al., 2008), and amount of irrigated water (Turner, 2013). Other studies have been carried out on the efficiency of irrigation systems separately, but still, there is demand for studies testing the responses of phytotechnical and physiological traits of Pome type bananas to different irrigation systems in field conditions.

Based on the above-mentioned, the present study aimed to evaluate the gas exchanges of Pome type banana trees submitted to different irrigation systems.

\section{MATERIAL AND METHODS}

The assay was installed in the experimental area of the Instituto Federal Baiano (Federal Institute of Bahia), in Guanambi Campus, Bahia state, Brazil. The local soil is classified as a Red-Yellow Latosol. The mean annual rainfall and temperature are $680.0 \mathrm{~mm}$ and $26{ }^{\circ} \mathrm{C}$, respectively. On January 31 of 2008, micropropagated

\footnotetext{
${ }^{2}$ Federal Institute Baiano/ Guanambi - BA, Brazil.

${ }^{3}$ Federal University Viçosa/ Viçosa - MG, Brazil.

${ }^{4}$ Embrapa Cassava and Fruits/ Cruz das Almas - BA, Brazil.

Received in: 4-18-2016

Accepted in: 12-11-2017
} 
seedlings of 'Prata-Anã' and 'BRS Platina' banana cultivars were planted, spaced by $3.0 \times 2.5 \mathrm{~m}$. Crop implementation, fertilization, and management followed the recommendations provided by Rodrigues et al. (2015) for this specific plant.

Seventy-two treatments were conducted in a $2 \times 3 \times 12$ factorial scheme. The factors consisted of two cultivars ['Prata-Anã' (AAB) and its progeny 'BRS Platina' (AAAB)], three irrigation systems (conventional under-tree sprinklers, micro-sprinklers, and dripping), and 12 evaluation months (from October 2009 to September 2010). Treatments were arranged in a fully randomized design with five repetitions. Each experimental plot was composed of one plant fully bordered.

Three irrigation systems were tested in this experiment: I) an under-tree conventional sprinkling with sectoral sprinklers (model 427 1/2"; NaaDan Indústria e Comércio de Equipamentos para Irrigação Ltda., Leme SP, Brazil), with a $1,500 \mathrm{~L} \mathrm{~h}^{-1}$ water outflow and $3.2-\mathrm{mm}$ nozzles spaced $12 \mathrm{~m}$ between side lines and $12 \mathrm{~m}$ between sprinklers; II) pressure compensating micro-sprinkling with Netafim emitters (Netafim Israel, Kibbutz Hatzerim, Israel), with a $70 \mathrm{~L} \mathrm{~h}^{-1}$ water outflow, 6-m wetting diameter, and $1.33-\mathrm{mm}$ green nozzles spaced $6 \mathrm{~m}$ between side lines and $5 \mathrm{~m}$ between emitters; III) a dripping system with one lateral drip line per plant row and over the ground emitters (model Catif; Plastro Brasil Sistemas de Irrigação, Uberlândia, MG, Brazil), with a $2.3 \mathrm{~L} \mathrm{~h}^{-1}$ water outflow and spaced $3 \mathrm{~m}$ between side lines and 0.30 $m$ between emitters.

Irrigation was managed based on crop
evapotranspiration (ETc) from reference evapotranspiration (ETo) and crop coefficient (Kc). ETo was indirectly calculated by the Penman-Monteith method according to FAO bulletin 56 and based on data from a weather station in the IF Baiano (Guanambi Campus), installed near the experimental areas. The mean water depth used in each system was $5.04 \mathrm{~mm}$ a day; however, the amount of water varied throughout the experiment and considered each system application efficiency, which was 90,85 , and $80 \%$ for dripping, micro-sprinkling, and conventional sprinkling, respectively.

The Kc values used for crop evapotranspiration calculation during irrigation management followed Equation 1, as described by Borges et al. (2011). From implementation until banana seedling young phase, i.e. the first 120 days after transplanting (DAT), the water depth was the same for all treatments. From then on, the Kc values varied approximately between 0.60 and 1.4 from 120 to 300 DAT, respectively. These values were maintained in all subsequent cycles up to the end of the crop cycle. Yet the coefficient of location (Kl) was calculated based on the shaded area of the plant or on the emitter wetting area, depending on which one was the highest.

Equation 1: $\mathrm{Kc}=0.704-6.443 \times 10-3 \mathrm{DAP}+6.437 \times 10-5$ $\mathrm{DAP}^{2}-1.174$ x 10-7 DAP3 $\mathrm{R}^{2}=0.978$;

The vegetative characteristics were measured during the flowering stage of the third production cycle.
These traits consisted of plant height, distance from soil level to leaf rosette, pseudostem perimeter at soil level, number of functional leaves (i.e. unbroken or with at least $50 \%$ of their leaf blade intact). During the third cycle harvest, the number of functional leaves and yield characteristics (mass of the hands, number of hands per bunch and bunch mass) was measured for each useful plant, following the procedures adopted by Donato et al. (2006; 2009). Total leaf area was determined according to Zucoloto et al. (2008) and the leaf area index (LAI) was calculated by the formula: LAI = TLA/area occupied by the plant $\left(\mathrm{m}^{2} / \mathrm{m}^{2}\right)$.

Gas exchange, leaf temperature, and incident radiation were assessed in the third or fourth leaf from the top to bottom by an infrared gas analyzer (IRGA), LCpro $^{+\circledR}$ Portable Photosynthesis System model (ADC Bioscientific Limited, UK). The measures were made at ambient temperature and irradiation, and with an airflow of $200 \mathrm{~mL} \mathrm{~min}^{-1}$, always with the radiation shield directed towards the sun.

Twelve assessments were conducted at monthly intervals, at five different times of day $(8 \mathrm{am}, 10 \mathrm{am}, 12$ $\mathrm{pm}, 2 \mathrm{pm}$, and $4 \mathrm{pm})$. Leaf temperature $\left(T_{\text {leaf }} ;{ }^{\circ} \mathrm{C}\right)$, transpiration $\left(E ;\right.$ mmol $\left.\mathrm{H}_{2} \mathrm{O} \mathrm{m} \mathrm{m}^{-2}\right)$, liquid photosynthes is (A; $\left.\mu \mathrm{mol} \mathrm{CO}_{2} \mathrm{~m}^{-2} \mathrm{~s}^{-1}\right)$, instant water-use efficiency $(A / E$; $\left.\mu \mathrm{mol} \mathrm{CO}_{2} \mathrm{~m}^{-2} \mathrm{~s}^{-1} / \mathrm{mmol} \mathrm{H}_{2} \mathrm{O} \mathrm{m}^{-2} \mathrm{~s}^{-1}\right)$, and carboxylation efficiency $\left(A / C_{i}\right)$.

Statistical analysis was performed as follows: 1) plant vegetative and yield characteristics were analyzed in a two-factor design ( 3 irrigation systems and 2 cultivars) in a fully randomized design (FRD). The data underwent variance analysis to check for interaction significance, and means were compared by Tukey's test $(\mathrm{P}<0.05)$; 2) plant physiological characteristics were arranged in a $3 \times 2 \times 12$ factorial scheme in an FRD (2 irrigation systems, 2 cultivars, and 12 months). These data were also submitted to variance analysis and, when interactions were significant, factors were analy zed individually.

The averages were compared using the $\mathrm{F}$ and the Tukey tests $(\mathrm{P}<0.05)$ for both cultivar and irrigation system factors, respectively; then, they were grouped together by the Scott-Knott criteria $(\mathrm{P}<0.05)$ for the monthly evaluation factor. Correlation and regression studies were conducted for the variables, and the mathematical models were adjusted according to beta significance, determination coefficient, correlation coefficient, and the difference between them.

\section{RESULTS AND DISCUSSION}

During the third cycle, the plant parameters varied according to banana cultivar and irrigation system, in an independent manner, with no interaction between them (Table 1). These results were similar to those found by Marques et al. (2011), who also observed no significant interactions between cultivars and irrigation systems, except for number of fruits per hand in the first cycle and mass of hands in the second one. 
TABLE 1. Vegetative and yield characteristics assessed during the third production cycle of 'Prata-Anã' and 'BRS Platina' banana cultivars, under conventional sprinkling, micro-sprinkling, and dripping irrigation systems. Guanambi, BA, $2009-2010$.

\begin{tabular}{|c|c|c|c|c|c|c|}
\hline \multirow{2}{*}{ Characteristics } & \multicolumn{3}{|c|}{ Irrigation Systems } & \multicolumn{2}{|c|}{ Cultivars } & \multirow{2}{*}{$\begin{array}{l}\mathrm{CV} \\
(\%)\end{array}$} \\
\hline & Micro & Sprin kling & Dripping & 'BRS Platina' & 'Prata-Anã' & \\
\hline Plant height (cm) & $396.58 \mathrm{a}$ & $395.46 \mathrm{ab}$ & $371.62 b$ & $391.92 \mathrm{a}$ & $383.86 a$ & 9.11 \\
\hline Perimeter of ps eudostem $(\mathrm{cm})$ & $127.33 \mathrm{a}$ & $127.37 \mathrm{a}$ & $116.46 \mathrm{~b}$ & $120.55 b$ & $126.88 \mathrm{a}$ & 7.63 \\
\hline Nu mber of leaves at flowering & $17.00 \mathrm{a}$ & $16.83 \mathrm{a}$ & $17.12 \mathrm{a}$ & $15.47 \mathrm{~b}$ & $18.50 \mathrm{a}$ & 13.11 \\
\hline Number of leaves at harvest & $11.00 \mathrm{a}$ & $11.38 \mathrm{a}$ & $11.92 \mathrm{a}$ & $10.11 \mathrm{~b}$ & $12.75 \mathrm{a}$ & 19.80 \\
\hline Leaf area $\left(\mathrm{m}^{2}\right)$ & $17.58 \mathrm{a}$ & $17.38 \mathrm{a}$ & $17.96 \mathrm{a}$ & $16.28 \mathrm{~b}$ & $19.00 \mathrm{a}$ & 23.39 \\
\hline Numbers of hands per bunch & $11.21 \mathrm{a}$ & $11.37 \mathrm{a}$ & $10.42 b$ & $9.92 b$ & $12.08 \mathrm{a}$ & 10.33 \\
\hline Bunch mass (kg) & $23.73 a$ & $23.98 \mathrm{a}$ & $23.45 \mathrm{a}$ & $24.37 \mathrm{a}$ & $22.51 \mathrm{a}$ & 23.16 \\
\hline Hand mass $(\mathrm{kg})$ & $20.65 \mathrm{a}$ & $21.02 \mathrm{a}$ & $19.74 \mathrm{a}$ & $20.13 a$ & $20.81 \mathrm{a}$ & 23.10 \\
\hline
\end{tabular}

(1) Averages, followed by the same letters in the lines, displayed no differences amongst themselves for irrigation systems, verified by the Tukey test, and for the cultivars, verified by the F Test, at $5 \%$ probability.

Plant height only differed among irrigation systems $(\mathrm{P}<0.05)$, regardless of the cultivar (Table 1). These results are in agreement with the results obtained by Marques et al. (2011), and confirm the statements made by Donato et al. (2006; 2009) that 'Prata-Anã' and 'BRS Platina' have similar sizes. Banana plants irrigated by micro-sprinklers were taller $(396.58 \mathrm{~cm})$ if compared to those irrigated by dripping $(371.63 \mathrm{~cm})$, which is probably due to the differences in root system distribution in the soil (Sant'ana et al., 2012).

The pseudostem perimeter at soil level differed for each irrigation system and cultivar in an independent manner. The results were higher for banana plants irrigated by micro-sprinkling and conventional under-tree sprinkling, being of 127.33, and $127.37 \mathrm{~cm}$, respectively. However, the results were lower for banana plants treated with dripping $(116.46 \mathrm{~cm})$. These results are all in agreement with Marques et al. (2011).

Plant heights and pseudostem perimeters responded to environmental and management factors, showing the vigor of plants. This first was mostly affected by management and environmental factors, which can limit cultivation in regions with strong winds (Soto Ballestero, 2008), while the second represents the number of emitted leaves and can alter the number of hands (Robinson \& Galán Saúco, 2010).

The number of functional leaves at flowering and at harvest and the total leaf area were influenced exclusively by the cultivars, regardless of the irrigation system (Table 1). The number of functional leaves at flowering and harvesting and the leaf area were 18.5, 12.75, $19.0 \mathrm{~m}^{2}$ for the cultivar 'Prata- Anã', and 15.47, 10.11, and $16.28 \mathrm{~m}^{2}$ for the cultivar 'BRS Platina', respectively (Table 1). The number of live leaves has an influence on the factors leaf area and leaf area index; this number depends on climatic and management conditions, being related to light absorption and energy.

The vegetative characteristics varied according to the cultivar, except for plant height that was higher for the cultivar 'Prata-Anã' (Table 1). These results are similar to those found by Donato et al. (2006) and Marques et al. (2011) and displayed the genetic differences between both them. The cultivar 'Prata-Anã' showed a larger number of leaves than does the 'BRS Platina', regardless of the irrigation system. Donato et al. (2009) have already reported different results when in the presence of yellow Sigatoka. According to these authors, both cultivars have a similar number of leaves when affected by such disease. In contrast, Oliveira et al. (2008) reg istered a higher nu mber of leaves for 'BRA Platina', when in the presence of black Sigatoka, which might be because of its resistance to the disease (Olive ira et al., 2008).

The number of hands per bunch differed independently among irrigation systems and cultivars (Table 1). Banana plants irrigated by micro-sprinklers and conventional sprinklers presented a larger number of bunches (11) when compared to the dripping irrigation system (10). Concerning the cultivars, the 'Prata-Anã' presented a larger nu mber of hands per bunch (12) than did 'BRS Platina' plants (10), regardless of the irrigation system (Table 1), which is in agreement with Donato et al. (2006; 2009). Marques et al. (2011) reported larger hand sizes and bunch masses in the second production cycle for plants irrigated by micro-sprinklers when compared to those irrigated by dripping, in the same experimental conditions.

Significant interactions were observed at all five assessment times for all the assessed factors and for all the studied physiological characteristics (Tables 2, 3, 4, 5, and 6). We expected to find physiological differences between the two genotypes when irrigated with different systems, which would allow their grouping according to the seasons of the year. However, the differences between the months prevented grouping by the Scott-Knott criteria $(\mathrm{P}<0.05)$.

The leaf temperature $\left(T_{\text {leaf }}\right)$ for each banana plant cultivar differed in all irrigation systems and assessment times. By and large, 'BRS Platina' showed the lower results while 'Prata-Anã' the higher ones. At all assessments times, both cultivars presented different $T_{\text {leaf }}$ values for the different irrigation systems most months. In most cases, if compared to the plants irrigated by microsprinkling, leaf temperature was higher in both cultivars when irrigated by dripping. 
TABLE 2. Physiological variables measured at 8 a.m. on the third sheet of 'Prata-Anã' and 'BRS Platina' banana plants in their third cycle of production, grown in three different irrigation systems from October 2009 to September 2010 in Guanambi, BA.

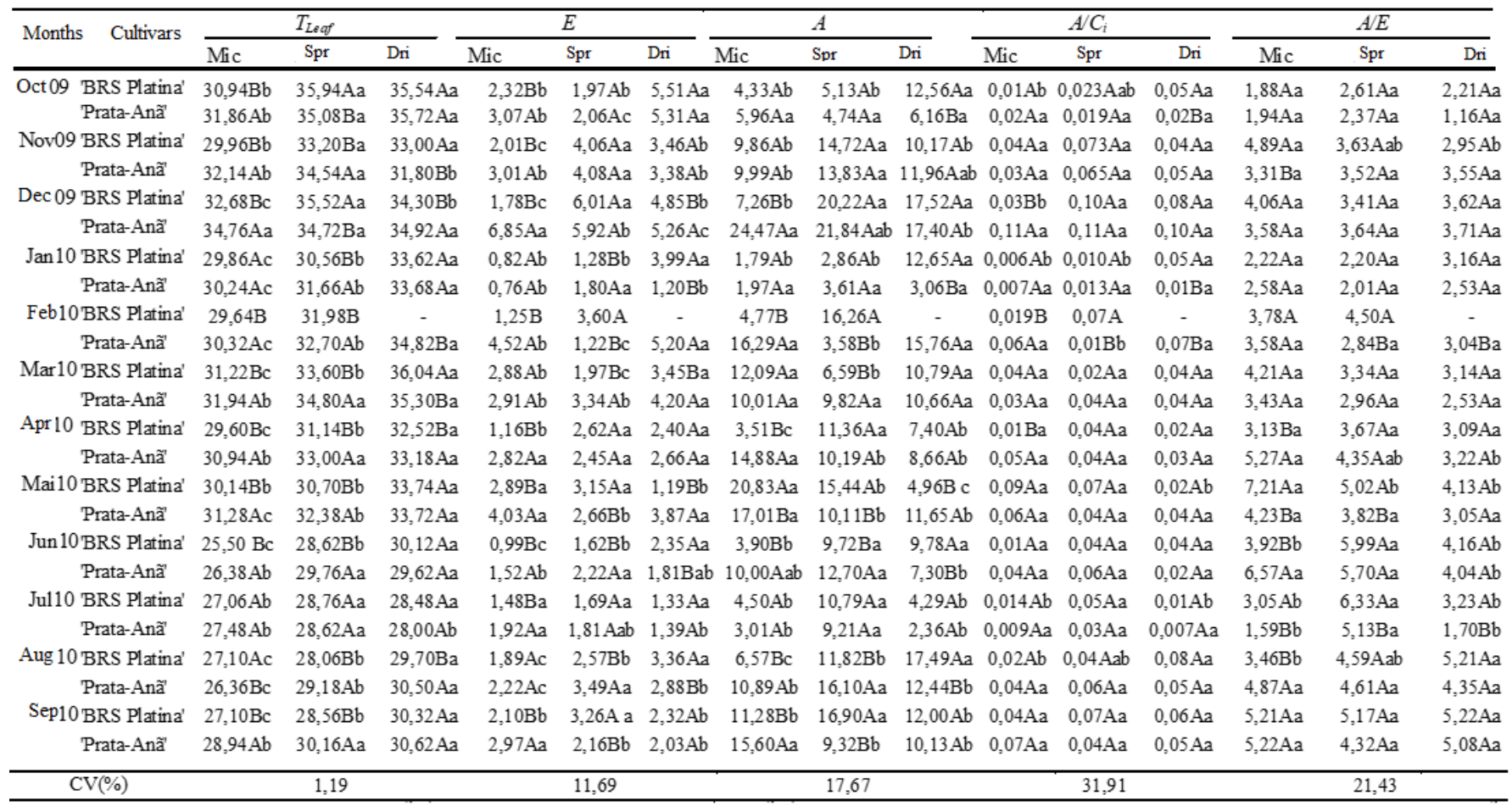

$T_{\text {leaf }}\left({ }^{\circ} \mathrm{C}\right)$ : Leaf temperature; $E\left(\mathrm{mmol} \mathrm{H}_{2} \mathrm{O} \mathrm{m} \mathrm{m}^{-2} \mathrm{~s}^{-1}\right)$ : Transpiration rate; $A\left(\mu \mathrm{mol} \mathrm{CO}_{2} \mathrm{~m}^{-2} \mathrm{~s}^{-1}\right)$; Photosynthesis rate; $A / C i$ : $\mathrm{CO}_{2}$ Carboxylation efficiency; $A / E\left(\left(\mu \mathrm{mol} \mathrm{CO} \mathrm{m}^{-2} \mathrm{~s}^{-1} / \mathrm{mmol} \mathrm{H}_{2} \mathrm{O} \mathrm{m}^{-2} \mathrm{~s}^{-1}\right)\right.$ : Instant water use efficiency; Mic: Micro-sprinkling sy stem; Spr: Conventional undertree sprinkling sy stem; Dri: Dripping irrigation system.

*Average followed by the same letter, upper case in the columns for cultivars, and lower case in the lines for irrigation systems, had no difference amongst each other, verified by the $\mathrm{F}$ Test and the Tukey Test at $5 \%$ probability, respectively.

TABLE 3. Physiological variables measured at 10 a.m. on the third sheet of 'Prata-Anã' and 'BRS Platina' banana plants in their third cycle of production, grown in three different irrigation systems from October 2009 to September 2010 in Guanambi, BA.

\begin{tabular}{|c|c|c|c|c|c|c|c|c|c|c|c|c|c|c|c|}
\hline \multirow{2}{*}{ Cultivars } & \multicolumn{3}{|c|}{$T_{\text {Leaf }}$} & \multicolumn{3}{|c|}{$E$} & \multicolumn{3}{|c|}{$A$} & \multicolumn{3}{|c|}{$A / C_{i}$} & \multicolumn{3}{|c|}{$A / E$} \\
\hline & $\overline{M i c}$ & Spr & Dri & Mic & Spr & Dri & Mic & Spr & Dri & Mic & Spr & Dri & Mic & Spr & Dri \\
\hline Oct09 'BRS Platina' & $92 \mathrm{Bc}$ & $36,32 \mathrm{Bb}$ & $38,18 \mathrm{Aa}$ & $2,87 \mathrm{Bb}$ & $3,51 \mathrm{Bb}$ & $6,46 \mathrm{Ba}$ & $5,69 \mathrm{Bb}$ & $6,32 \mathrm{Bb}$ & $10,66 \mathrm{Aa}$ & $0,020 \mathrm{Bb}$ & $0,024 \mathrm{Bb}$ & $0,043 \mathrm{Aa}$ & $2,02 \mathrm{Aa}$ & $1,79 \mathrm{Aa}$ & $\overline{1,63 \mathrm{Aa}}$ \\
\hline 'Prata-Anã' & $37,28 \mathrm{Ab}$ & $38,34 \mathrm{Aa}$ & $38,42 \mathrm{Aa}$ & $3,95 \mathrm{Ac}$ & $5,56 \mathrm{Ab}$ & $7,47 \mathrm{Aa}$ & $9,23 \mathrm{Ab}$ & $9,74 \mathrm{Aab}$ & $11,80 \mathrm{Aa}$ & $0,042 \mathrm{Aa}$ & $0,039 \mathrm{Aa}$ & $0,045 \mathrm{Aa}$ & $2,34 \mathrm{Aa}$ & $1,74 \mathrm{Aab}$ & $1,57 \mathrm{Ab}$ \\
\hline Nov09 'BRS Platina' & $31,08 \mathrm{Bc}$ & $34,00 \mathrm{Bb}$ & $35,34 \mathrm{Ba}$ & $2,73 \mathrm{Bc}$ & $4,23 \mathrm{Bb}$ & $5,33 \mathrm{Ba}$ & $13,2 \mathrm{Ab}$ & $15,85 \mathrm{Aa}$ & $16,92 \mathrm{Aa}$ & $0,061 \mathrm{Ab}$ & $0,073 \mathrm{Aab}$ & $0,076 \mathrm{Aa}$ & $5,00 \mathrm{Aa}$ & $3,77 \mathrm{Ab}$ & $3,19 \mathrm{Ab}$ \\
\hline 'Prata-Anã' & $32,28 \mathrm{Ac}$ & $34,94 \mathrm{Ab}$ & $37,04 \mathrm{Aa}$ & $3,83 \mathrm{Ac}$ & $5,11 \mathrm{Ab}$ & $7,09 \mathrm{Aa}$ & $13,53 \mathrm{Ab}$ & $14,52 \mathrm{Ab}$ & $18,51 \mathrm{Aa}$ & $0,055 \mathrm{Ab}$ & $0,061 \mathrm{Ab}$ & $0,080 \mathrm{Aa}$ & $3,55 \mathrm{Ba}$ & $2,83 \mathrm{Bab}$ & $2,61 \mathrm{Ab}$ \\
\hline Dec 09 'BRS Platina' & $32,30 \mathrm{Bc}$ & $35,82 \mathrm{Bb}$ & $38,44 \mathrm{Aa}$ & $3,40 \mathrm{Ab}$ & $3,43 \mathrm{Bb}$ & $8,66 \mathrm{Aa}$ & $3,02 \mathrm{Bb}$ & $4,07 \mathrm{Bb}$ & $21,75 \mathrm{Aa}$ & $0,009 \mathrm{Bb}$ & $0,014 \mathrm{Bb}$ & $0,093 \mathrm{Aa}$ & $0,91 \mathrm{Bb}$ & $1,19 \mathrm{Bb}$ & $2,51 \mathrm{Aa}$ \\
\hline 'Prata-Anã' & $33,00 \mathrm{Ac}$ & $37,06 \mathrm{Ab}$ & $38,68 \mathrm{Aa}$ & $3,88 \mathrm{Ac}$ & $6,89 \mathrm{Aa}$ & $5,95 \mathrm{Bb}$ & $6,71 \mathrm{Ac}$ & $20,35 \mathrm{Aa}$ & $13,56 \mathrm{Bb}$ & $0,023 \mathrm{Ac}$ & $0,093 \mathrm{Aa}$ & $0,058 \mathrm{Bb}$ & $1,72 \mathrm{Ab}$ & $2,97 \mathrm{Aa}$ & $2,28 \mathrm{Aab}$ \\
\hline Jan10 'BRS Platina' & $31,88 \mathrm{Bc}$ & $34,50 \mathrm{Bb}$ & $37,38 \mathrm{Ba}$ & $1,92 \mathrm{Bb}$ & $2,32 \mathrm{Bb}$ & $5,69 \mathrm{Aa}$ & $5,35 \mathrm{Ab}$ & $2,71 \mathrm{Bc}$ & $11,73 \mathrm{Aa}$ & $0,020 \mathrm{Ab}$ & $0,009 \mathrm{Bb}$ & $0,050 \mathrm{Aa}$ & $2,78 \mathrm{Aa}$ & $1,18 \mathrm{Bc}$ & $2,06 \mathrm{Ab}$ \\
\hline 'Prata-Anã' & $34,62 \mathrm{Ac}$ & $36,68 \mathrm{Ab}$ & $38,52 \mathrm{Aa}$ & $4,25 \mathrm{Aa}$ & $4,13 \mathrm{Aa}$ & $4,42 \mathrm{Ba}$ & $5,68 \mathrm{Ab}$ & $9,83 \mathrm{Aa}$ & $7,85 \mathrm{Bab}$ & $0,018 \mathrm{Ab}$ & $0,045 \mathrm{Aa}$ & $0,037 \mathrm{Ba}$ & $1,34 \mathrm{Bb}$ & $2,37 \mathrm{Aa}$ & $1,77 \mathrm{Aab}$ \\
\hline $\begin{array}{c}\text { 'Prata-Ană' } \\
\text { Feb10'BRS Platina' }\end{array}$ & $30,40 \mathrm{Bb}$ & $31,18 \mathrm{Aa}$ & $31,58 \mathrm{Aa}$ & $3,24 \mathrm{Aa}$ & $2,78 \mathrm{Aa}$ & $3,05 \mathrm{Aa}$ & $13,87 \mathrm{Aa}$ & $13,18 \mathrm{Aa}$ & $12,53 \mathrm{Aa}$ & $0,052 \mathrm{Aa}$ & $0,065 \mathrm{Aa}$ & $0,056 \mathrm{Aa}$ & $4,28 \mathrm{Aa}$ & $4,73 \mathrm{Aa}$ & $4,14 \mathrm{Aa}$ \\
\hline \multirow{2}{*}{$\begin{array}{c}\text { 'Prata-Anã' } \\
\text { Mar10 'BRS Platina' }\end{array}$} & $30,78 \mathrm{Ab}$ & $31,50 \mathrm{Aa}$ & $31,36 \mathrm{Aa}$ & $2,85 \mathrm{Aa}$ & $2,52 \mathrm{Aa}$ & $2,97 \mathrm{Aa}$ & $9,15 \mathrm{Ba}$ & $11,22 \mathrm{Aa}$ & $9,19 \mathrm{Ba}$ & $0,035 \mathrm{Ab}$ & $0,054 \mathrm{Aa}$ & $0,035 \mathrm{Bb}$ & $3,21 \mathrm{Bb}$ & $4,44 \mathrm{Aa}$ & $3,08 \mathrm{Bb}$ \\
\hline & $33,02 \mathrm{Bc}$ & $36,70 \mathrm{Bb}$ & $39,36 \mathrm{Ba}$ & $3,49 \mathrm{Bb}$ & $5,23 \mathrm{Ba}$ & $5,50 \mathrm{Ba}$ & $15,23 \mathrm{Aa}$ & $15,35 \mathrm{Ba}$ & $11,84 \mathrm{Ab}$ & $0,063 \mathrm{Aab}$ & $0,072 \mathrm{Aa}$ & $0,054 \mathrm{Bb}$ & $4,38 \mathrm{Aa}$ & $3,04 \mathrm{Ab}$ & $2,19 \mathrm{AC}$ \\
\hline \multirow{2}{*}{$\begin{array}{c}\text { 'Prata-Anã' } \\
\text { Apr } 10 \text { 'BRS Platina' }\end{array}$} & $35,82 \mathrm{Ac}$ & $38,48 \mathrm{Ab}$ & $40,06 \mathrm{Aa}$ & $5,21 \mathrm{Ac}$ & $7,81 \mathrm{Aa}$ & $6,39 \mathrm{Ab}$ & $14,99 \mathrm{Aa}$ & $17,54 \mathrm{Ab}$ & $13,86 \mathrm{Ab}$ & $0,058 \mathrm{Ab}$ & $0,073 \mathrm{Aa}$ & $0,068 \mathrm{Aab}$ & $2,92 \mathrm{Ba}$ & $2,24 \mathrm{Bab}$ & $2,18 \mathrm{Ab}$ \\
\hline & $32,52 \mathrm{Bc}$ & $35,18 \mathrm{Ab}$ & $36,62 \mathrm{Ba}$ & $2,65 \mathrm{Bb}$ & $3,15 \mathrm{Ab}$ & $5,24 \mathrm{Aa}$ & $10,26 \mathrm{Bb}$ & $11,72 \mathrm{Ab}$ & $16,69 \mathrm{Aa}$ & $0,037 \mathrm{Bb}$ & $0,046 \mathrm{Ab}$ & $0,072 \mathrm{Aa}$ & 3,91Aa & $3,86 \mathrm{Aa}$ & $3,20 \mathrm{Aa}$ \\
\hline \multirow{2}{*}{$\begin{array}{c}\text { 'Prata-Anã' } \\
\text { Mai10 'BRS Platina' }\end{array}$} & $34,28 \mathrm{Ac}$ & $35,02 \mathrm{Ab}$ & $37,24 \mathrm{Aa}$ & $3,58 \mathrm{Aa}$ & $2,63 \mathrm{Ab}$ & 2,93Bab & $15,33 \mathrm{Aa}$ & $3,61 \mathrm{Bc}$ & $6,51 \mathrm{Bb}$ & $0,060 \mathrm{Aa}$ & $0,012 \mathrm{Bc}$ & $0,026 \mathrm{Bb}$ & $4,23 \mathrm{Aa}$ & $1,40 \mathrm{Bb}$ & $1,90 \mathrm{Bb}$ \\
\hline & $33,74 \mathrm{Bc}$ & $37,30 \mathrm{Ab}$ & $40,44 \mathrm{Aa}$ & $2,68 \mathrm{Bb}$ & $7,18 \mathrm{Aa}$ & $1,07 \mathrm{Bc}$ & $8,862 \mathrm{Bb}$ & $22,23 \mathrm{Aa}$ & $1,98 \mathrm{Bc}$ & $0,032 \mathrm{Bb}$ & $0,098 \mathrm{Aa}$ & $0,009 \mathrm{Bc}$ & $3,27 \mathrm{Aa}$ & $3,12 \mathrm{Aa}$ & $1,84 \mathrm{Bb}$ \\
\hline \multirow{2}{*}{$\begin{array}{c}\text { 'Prata-Anã' } \\
\text { Jun10'BRS Platina' }\end{array}$} & $35,86 \mathrm{Ab}$ & $38,10 \mathrm{Aa}$ & $38,10 \mathrm{Ba}$ & $5,81 \mathrm{Aa}$ & $5,94 \mathrm{Ba}$ & $5,94 \mathrm{Aa}$ & $18,11 \mathrm{Aa}$ & $17,16 \mathrm{Ba}$ & $17,16 \mathrm{Aa}$ & $0,075 \mathrm{Aa}$ & $0,080 \mathrm{Ba}$ & $0,080 \mathrm{Aa}$ & $3,14 \mathrm{Aa}$ & $2,89 \mathrm{Aa}$ & $2,89 \mathrm{Aa}$ \\
\hline & $31,18 \mathrm{Bc}$ & $32,80 \mathrm{Ab}$ & $34,40 \mathrm{Ba}$ & $3,37 \mathrm{Ab}$ & $5,08 \mathrm{Aa}$ & $2,82 \mathrm{Bb}$ & $9,258 \mathrm{Ba}$ & $6,26 \mathrm{Ab}$ & $8,17 \mathrm{Bab}$ & 0,033Ba & $0,019 \mathrm{Ab}$ & $0,037 \mathrm{Ba}$ & $2,80 \mathrm{Ba}$ & $1,22 \mathrm{Bb}$ & $2,98 \mathrm{Aa}$ \\
\hline \multirow{2}{*}{$\begin{array}{c}\text { 'Prata-Anã' } \\
\text { Jul10 'BRS Platina' }\end{array}$} & $32,52 \mathrm{Ab}$ & $32,86 \mathrm{Ab}$ & $35,30 \mathrm{Aa}$ & $3,80 \mathrm{Ab}$ & $3,90 \mathrm{Aa}$ & $6,12 \mathrm{Ab}$ & $13,76 \mathrm{Ab}$ & $7,95 \mathrm{Ac}$ & $19,71 \mathrm{Aa}$ & $0,057 \mathrm{Ab}$ & $0,029 \mathrm{Ac}$ & $0,091 \mathrm{Aa}$ & $3,62 \mathrm{Aa}$ & $2,24 \mathrm{Ab}$ & $3,21 \mathrm{Aa}$ \\
\hline & $29,38 \mathrm{Bc}$ & $31,56 \mathrm{Ab}$ & $33,22 \mathrm{Ba}$ & $1,97 \mathrm{Ab}$ & $3,48 \mathrm{Aa}$ & $2,98 \mathrm{Aa}$ & $9,21 \mathrm{Ab}$ & $13,27 \mathrm{Aa}$ & $10,94 \mathrm{Aab}$ & $0,037 \mathrm{Ab}$ & $0,055 \mathrm{Aa}$ & $0,052 \mathrm{Ba}$ & $4,67 \mathrm{Ba}$ & $3,81 \mathrm{Ab}$ & $3,67 \mathrm{Ab}$ \\
\hline \multirow{2}{*}{ Aug 10 'BRS Platina' } & $30,76 \mathrm{Ac}$ & $31,50 \mathrm{Ab}$ & $34,64 \mathrm{Aa}$ & $1,90 \mathrm{Ab}$ & $2,07 \mathrm{Bb}$ & $3,34 \mathrm{Aa}$ & $9,35 \mathrm{Ab}$ & $6,27 \mathrm{Bc}$ & $12,63 \mathrm{Aa}$ & $0,043 \mathrm{Ab}$ & $0,024 \mathrm{Bc}$ & $0,066 \mathrm{Aa}$ & $4,91 \mathrm{Aa}$ & $3,03 \mathrm{Bc}$ & $3,81 \mathrm{Ab}$ \\
\hline & $31,48 \mathrm{Bc}$ & $33,28 \mathrm{Bb}$ & $34,42 \mathrm{Ba}$ & $1,72 \mathrm{Bc}$ & $3,18 \mathrm{Ab}$ & $4,46 \mathrm{Aa}$ & $7,236 \mathrm{Bc}$ & $10,46 \mathrm{Ab}$ & $16,21 \mathrm{Aa}$ & $0,033 \mathrm{Bb}$ & $0,046 \mathrm{Ab}$ & $0,083 \mathrm{Aa}$ & $4,18 \mathrm{Aa}$ & $3,29 \mathrm{Ab}$ & $3,64 \mathrm{Aab}$ \\
\hline \multirow{3}{*}{$\begin{array}{c}\text { 'Prata-Anà' } \\
\text { Sep10 BRS Platina' } \\
\text { 'Prata-Anã' }\end{array}$} & $32,68 \mathrm{Ac}$ & $33,82 \mathrm{Ab}$ & $35,08 \mathrm{Aa}$ & $4,76 \mathrm{Aa}$ & $3,58 \mathrm{Ab}$ & $1,98 \mathrm{Bc}$ & $16,60 \mathrm{Aa}$ & $10,36 \mathrm{Ab}$ & $4,89 \mathrm{Bc}$ & $0,068 \mathrm{Aa}$ & $0,045 \mathrm{Ab}$ & $0,022 \mathrm{Bc}$ & $3,47 \mathrm{Ba}$ & $2,88 \mathrm{Aab}$ & $2,43 \mathrm{Bb}$ \\
\hline & $30,08 \mathrm{Bc}$ & $32,94 \mathrm{Bb}$ & $34,72 \mathrm{Aa}$ & $2,82 \mathrm{Bb}$ & $2,91 \mathrm{Bb}$ & $4,91 \mathrm{Aa}$ & $14,93 \mathrm{Ba}$ & $12,04 \mathrm{Bb}$ & $16,31 \mathrm{Aa}$ & $0,069 \mathrm{Bab}$ & $0,062 \mathrm{Bb}$ & $0,076 \mathrm{Aa}$ & $5,27 \mathrm{Aa}$ & $4,16 \mathrm{Ab}$ & $3,33 \mathrm{Ac}$ \\
\hline & $31,70 \mathrm{Ac}$ & $33,50 \mathrm{Ab}$ & $34,32 \mathrm{Ba}$ & $4,15 \mathrm{Aa}$ & $4,11 \mathrm{Aa}$ & $3,05 \mathrm{Bb}$ & $18,17 \mathrm{Aa}$ & $15,83 \mathrm{Aa}$ & $11,22 \mathrm{Bb}$ & $0,083 \mathrm{Aa}$ & $0,077 \mathrm{Aa}$ & $0,057 \mathrm{Bb}$ & $4,41 \mathrm{Ba}$ & $3,85 \mathrm{Aab}$ & $3,67 \mathrm{Ab}$ \\
\hline $\mathrm{CV}(\%)$ & & 0,83 & & & 12,31 & & & 14,29 & & & 18,19 & & & 21,43 & \\
\hline
\end{tabular}

$T_{\text {leaf }}\left({ }^{\circ} \mathrm{C}\right)$ : Leaf temperature; $E\left(\mathrm{mmol} \mathrm{H}_{2} \mathrm{O} \mathrm{m} \mathrm{m}^{-2} \mathrm{~s}^{-1}\right)$ : Transpiration rate; $A\left(\mu \mathrm{mol} \mathrm{CO}_{2} \mathrm{~m}^{-2} \mathrm{~s}^{-1}\right)$; Photosynthesis rate; $A / C i$ : $\mathrm{CO}_{2} \mathrm{Carboxy}$ lation efficiency; $A / E\left(\left(\mu \mathrm{mol} \mathrm{CO} \mathrm{CO}^{-2} \mathrm{~s}^{-1} / \mathrm{mmol} \mathrm{H}_{2} \mathrm{O} \mathrm{m}^{-2} \mathrm{~s}^{-1}\right)\right.$ : Instant water use efficiency; Mic: Micro-sprinkling sy stem; Spr: Conventional undertree sprinkling sy stem; Dri: Dripping irrigation system.

*Average followed by the same letter, upper case in the columns for cultivars, and lower case in the lines for irrigation systems, had no difference amongst each other, verified by the F Test and the Tukey Test at 5\% probability, respectively. 
TABLE 4. Physiological variables measured at 12 p.m. on the third sheet of 'Prata-Anã' and 'BRS Platina' banana plants in their third cycle of production, grown in three different irrigation systems from October 2009 to September 2010 in Guanambi, BA.

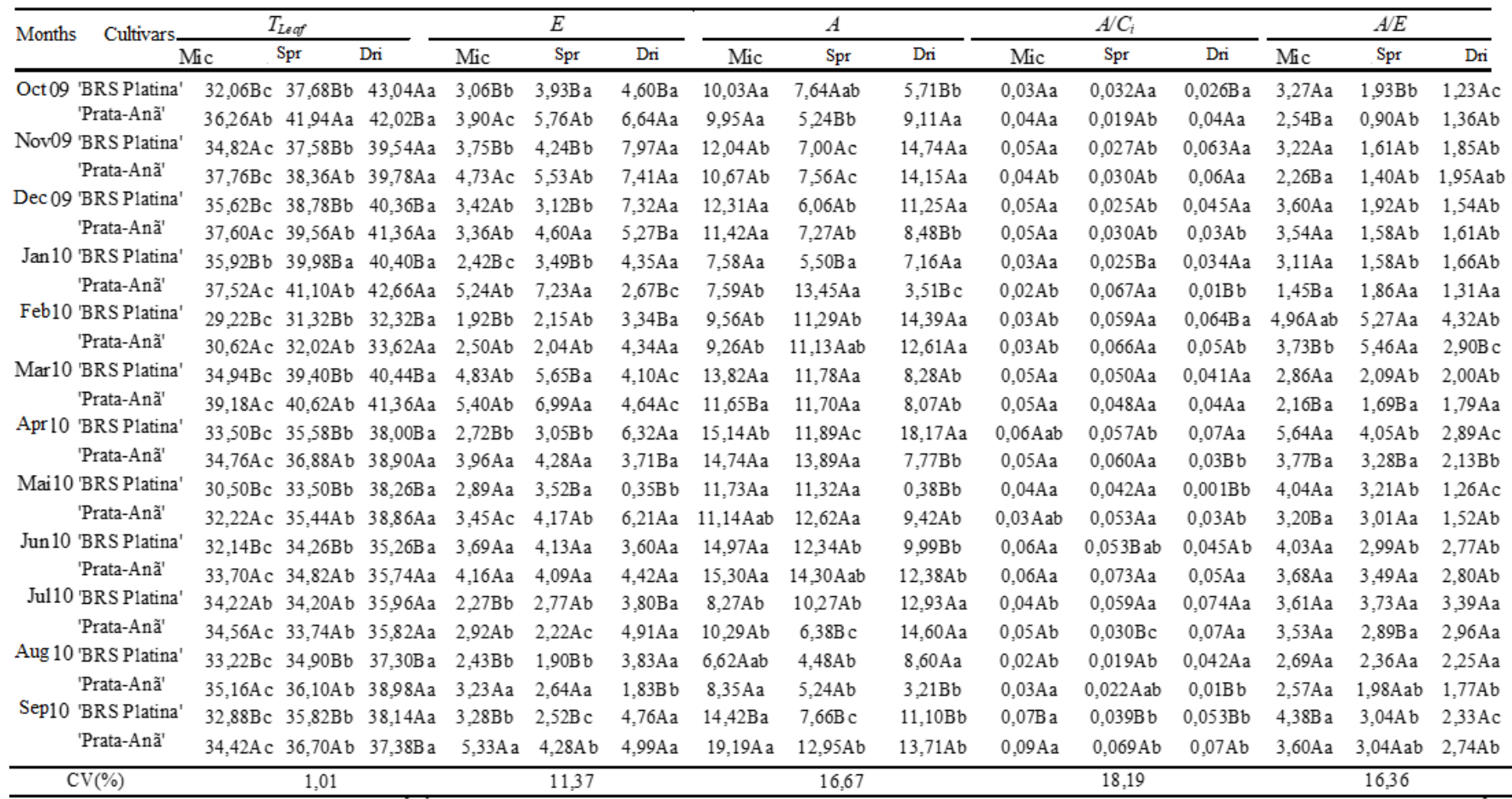

$T_{\text {leaf }}\left({ }^{\circ} \mathrm{C}\right)$ : Leaf temperature; $E\left(\mathrm{mmol} \mathrm{H}_{2} \mathrm{O} \mathrm{m} \mathrm{m}^{-2} \mathrm{~s}^{-1}\right)$ : Transpiration rate; $A\left(\mu \mathrm{mol} \mathrm{CO}_{2} \mathrm{~m}^{-2} \mathrm{~s}^{-1}\right)$; Photosynthesis rate; $A / C i$ : $\mathrm{CO}_{2}$ Carboxylation efficiency; $A / E\left(\left(\mu \mathrm{mol} \mathrm{CO} \mathrm{Cm}^{-2} \mathrm{~s}^{-1} / \mathrm{mmol} \mathrm{H}_{2} \mathrm{O} \mathrm{m}^{-2} \mathrm{~s}^{-1}\right)\right.$ : Instant water use efficiency; Mic: Micro-sprinkling sy stem; Spr: Conventional undertree sprinkling sy stem; Dri: Dripping irrigation sy stem.

*Average followed by the same letter, upper case in the columns for cultivars, and lower case in the lines for irrigation systems, had no difference amongst each other, verified by the F Test and the Tukey Test at 5\% probability, respectively.

TABLE 5. Physiological variables measured at 2 p.m. on the third sheet of 'Prata-Anã' and 'BRS Platina' banana plants in their third cycle of production, grown in three different irrigation systems from October 2009 to September 2010 in Guanambi, BA.

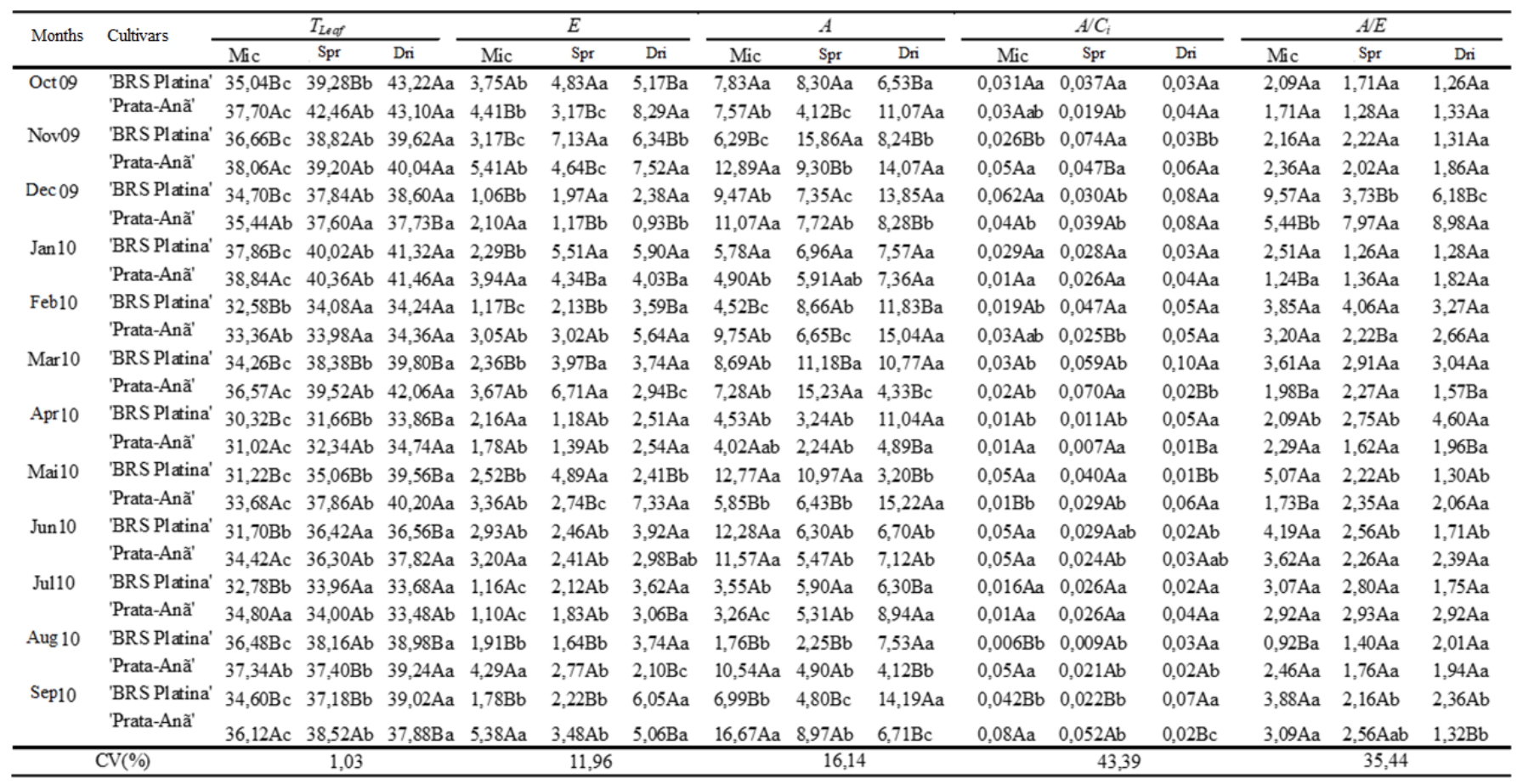

$T_{\text {leaf }}\left({ }^{\circ} \mathrm{C}\right)$ : Leaf temperature; $E\left(\mathrm{mmol} \mathrm{H}_{2} \mathrm{O} \mathrm{m}^{-2} \mathrm{~s}^{-1}\right)$ : Transpiration rate; $A$ ( $\mu \mathrm{mol} \mathrm{CO}_{2} \mathrm{~m}^{-2} \mathrm{~s}^{-1}$ ); Photosynthesis rate; $A / C i$ : $\mathrm{CO}_{2}$ Carboxylation efficiency; $A / E\left(\left(\mu \mathrm{mol} \mathrm{CO} \mathrm{m}^{-2} \mathrm{~s}^{-1} / \mathrm{mmol} \mathrm{H}_{2} \mathrm{O} \mathrm{m}^{-2} \mathrm{~s}^{-1}\right)\right.$ : Instant water use efficiency; Mic: Micro-sprinkling sy stem; Spr: Conventional undertree sprinkling sy stem; Dri: Dripping irrigation sy stem.

*Average followed by the same letter, upper case in the columns for cultivars, and lower case in the lines for irrigation systems, had no difference amongst each other, verified by the $\mathrm{F}$ Test and the Tukey Test at 5\% probability, respectively. 
TABLE 6. Physiological variables measured at 4 p.m. on the third sheet of 'Prata-Anã' and 'BRS Platina' banana plants in their third cycle of production, grown in three different irrigation systems from October 2009 to September 2010 in Guanambi, BA.

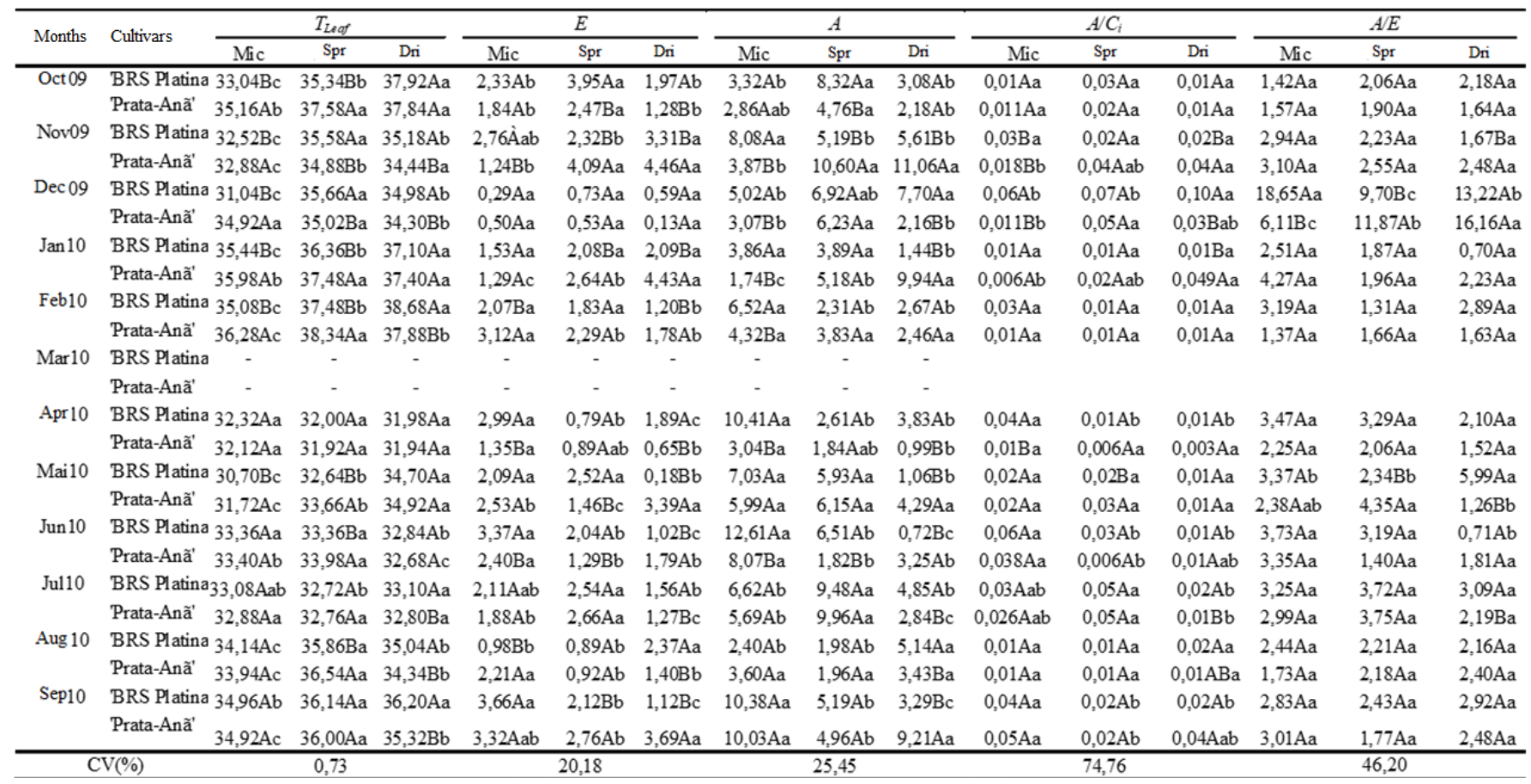

$T_{\text {leaf }}\left({ }^{\circ} \mathrm{C}\right)$ : Leaf temperature; $E\left(m m o l ~ \mathrm{H}_{2} \mathrm{O} \mathrm{m} \mathrm{m}^{-2} \mathrm{~s}^{-1}\right)$ : Transpiration rate; $A\left(\mu \mathrm{mol} \mathrm{CO}_{2} \mathrm{~m}^{-2} \mathrm{~s}^{-1}\right)$; Photosynthesis rate; $A / C i$ : $\mathrm{CO}_{2} \mathrm{Carboxy}$ lation efficiency; $A / E\left(\left(\mu \mathrm{mol} \mathrm{CO} \mathrm{m}^{-2} \mathrm{~s}^{-1} / \mathrm{mmol} \mathrm{H}_{2} \mathrm{O} \mathrm{m}^{-2} \mathrm{~s}^{-1}\right)\right.$ : Instant water use efficiency; Mic: Micro-sprinkling sy stem; Spr: Conventional undertree sprinkling sy stem; Dri: Dripping irrigation sy stem.

*Average followed by the same letter, upper case in the columns for cultivars, and lower case in the lines for irrigation systems, had no difference amon gst each other, verified by the $\mathrm{F}$ Test and the Tukey Test at $5 \%$ probability, respectively.

The water sprinkled onto the pseudostem exerts an additional cooling effect (sensible heat exchange) in plants. The longer term required to apply the same water depth by micro-sprinkling when compared to a conventional sprinkling might be due to the lower water flow of emitters, and can also be associated with the lower $T_{\text {leaf }}$ results reported.

During the hotter periods of the day, the leaves of both cultivars irrigated by dripping reached temperatures higher than $43.0^{\circ} \mathrm{C}$, which is close to the thermal damage point for banana plants (Robinson \& Galán Saúco, 2010). When studying the Williams cultivar, Thomas et al. (1998) observed that the maximum $T_{\text {leaf }}$ at which photosynthesis would be zero is between 43 and $44{ }^{\circ} \mathrm{C}$. This might be due to the extreme thermal damage caused by membrane rupture and denaturation of proteins. Although the aforementioned author defined the gas exchanges as the main response mechanism the effect of the pressure deficit and the density of the photosynthetically active flow, at the expense of the leaf te mperature $\left(T_{\text {leaf }}\right)$.

The transpiration rates $(E)$ measured by various authors in banana plants are similar to those observed in the present study (Thomas et al., 1998; Neves et al., 2002; Melo et al., 2009). The rates reported at the different times showed significant variation between cultivars irrigated by different watering systems, in most of the months, being the highest observed for the cultivar 'Prata-Anã'.

The variations of $E$ of the cultivars among the irrigations systems were observed in most of the months and at all assessment times, with the highest rates being registered in the dripping system and the lowest reported for the micro-sprinkling system, with the exception of the 4 p.m. assessment. This is probably because banana plants irrigated with micro-sprinklers presented lower leaf temperature, due to the better cooling provided by sprinkling the pseudostem of the plants with water. Furthermore, the continuous supply of water favors transpiration, which is proven by the inversion of the results at the 4 p.m. assessment caused by morning irrigation, simultaneous to the best conditions for physiological activities.

The hybrid exhibited higher $T_{\text {leaf }}$ when irrigated with the dripping system, moderate $T_{\text {leaf }}$ in conventional under-tree sprinkling and lowest $T_{\text {leaf }}$ in the microsprinkling system. This behavior is similar to that observed in most of the months and at all the assessment times for both cultivars. The highest $T_{\text {leaf }}$ result being reported in the dripping system was probably because it had no limiting effect on $A$, proven by the fact that the lowest $T_{\text {leaf }}$ average reported for 'BRS Platina' irrigated by micro-sprinklers $\left(29.60^{\circ} \mathrm{C}\right)$ and the highest average reported for 'Prata-Anã' $\left(33.18^{\circ} \mathrm{C}\right)$ are both within the optimum band gap for balance between growth and liquid absorption rate $\left(27^{\circ} \mathrm{C}\right)$, therefore, lower than the temperature which characterizes the beginning of the thermal stress in banana plants $\left(34^{\circ} \mathrm{C}\right)$ (Robinson \& Galán Saúco, 2010).

For 'Prata-Anã', in April 2010 at 8 a.m., higher $A$ was observed $\left(14.88 \mu \mathrm{mol} \mathrm{CO} \mathrm{Cm}^{-2} \mathrm{~s}^{-1}\right)$ when irrigated by micro-sprinklers, and lower levels of $A$ (11.36 and 8.66 $\mu \mathrm{mol} \mathrm{CO} \mathrm{CO}_{2}^{-2} \mathrm{~s}^{-1}$ ) when irrigated by dripping or sprinkling systems, respectively. The $T_{\text {leaf }}$ exhibited by the 'PrataAnã' cultivar when irrigated with micro-sprinklers was lower than the others were, as well as in most of the months in all assessment times. The combination of high $T_{\text {leaf }}$ and high levels of photosynthetically active radiation incident on the leaf $\left(Q_{\text {leaf }}\right)$ probably limited the $A$ of the 
cultivars irrigated by the dripping system, showing better water use efficiency when irrigating with the microsprinkling system.

Furthermore, in the month of April 2010, at 8 a.m., $E$ and $A$ were highest in 'BRS Platina' irrigated with the conventional sprinkling and dripping systems, and lowest in the plants irrigated with micro-sprinklers, although the internal $\mathrm{CO}_{2} \quad\left(C_{i}\right)$ and stomatal conductance $\left(g_{s}\right)$ concentrations showed no difference among systems. The lower $A$-level observed for this cultivar when irrigated by micro-sprinklers can be caused by the small differences in $g_{s}$ of the different systems, which are undetectable by the Tukey test $(\mathrm{P}<0.05)$, but still represent a difference of $220 \%$ from the lowest absolute value $\left(0.10 \mathrm{~mol} \mathrm{H}_{2} \mathrm{O} \mathrm{m}^{-2} \mathrm{~s}^{-}\right.$ $\left.{ }^{1}\right)$ to the highest $\left(0.32 \mathrm{~mol} \mathrm{H}_{2} \mathrm{O} \mathrm{m}^{-2} \mathrm{~s}^{-1}\right)$. Small variances in $g_{s}$ seem to cause higher variation in $E$ and in $A$.

The highest levels of $A$ occurred at 8 a.m. in the month of December 2009 in all irrigation systems for both banana plant cultivars, with the exception of 'BRS Platina' irrigated by the micro-sprinkling system. December 2009 presented a temperature high of $35^{\circ} \mathrm{C}$, as well as rainfall and higher humidity levels, which are favorable conditions for optimum physiology. $T_{\text {leaf }}$ of both cultivars were similar only when plants were irrigated by microsprinklers. BRS Platina showed lower $T_{\text {leaf }}$ when plants were irrigated by micro-sprinklers and there was no $T_{\text {leaf }}$ variance for 'Prata-Anã' in any of the systems. $E$ was highest in 'Prata-Anã' in all irrigation systems, except for in conventional sprinkling which showed similar results. Additionally, $A$ was lowest $\left(7.26 \mu \mathrm{mol} \mathrm{CO}_{2} \mathrm{~m}^{-2} \mathrm{~s}^{-1}\right)$ in 'BRS Platina' when irrigated with the micro-sprinkling system and coincided with the lowest levels of $E$ (1.78

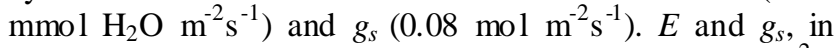
addition to the lower $A / C i$ proportion $\left(0.03 \mu \mathrm{mol} \mathrm{CO} \mathrm{Cm}^{-2} \mathrm{~s}^{-}\right.$ $1 / \mu \mathrm{mol} \quad \mathrm{CO}_{2} \mathrm{~mol}^{-1}$ ), an efficiency measurement for carboxylation of the rubisco enzyme whose decrease expresses a change in the direction of oxygenase activity, justify the reduction of $A$.

The assessment conducted at 10 a.m. reported different $A$ levels for each cultivar in all irrigation systems in most months (Table 3). When irrigated by microsprinklers and conventional sprinklers, the lowest levels of $A$ where exhibited by the 'BRS Platina' cultivar, while 'Prata-Anã' presented higher levels of $A$. The opposite was reported when plants were irrigated by the dripping system. Both cultivars had different levels of $A$ when irrigated by the different systems in most of the months. The highest $A$ levels were reported when irrigation was conducted by the dripping system in most of the months.

The rains in May 2009 raised air humidity, and maximum temperatures remained below $35{ }^{\circ} \mathrm{C}$. Under these conditions, alterations in gas exchange of 'BRS Platina' plants stood out, especially at 10 a.m., which had the highest results among the evaluated months. When irrigated by the conventional sprinkling system, the variables presented the following results: $Q_{\text {leaf }}(1.520$ $\mu \mathrm{mol}$ photons $\left.\mathrm{m}^{-2} \mathrm{~s}^{-1}\right) ; E\left(7.18 \mathrm{mmol} \mathrm{H}_{2} \mathrm{O} \mathrm{m}^{-2} \mathrm{~s}^{-1}\right) ; g_{s}(0.56$ mol $\left.\mathrm{H}_{2} \mathrm{O} \mathrm{m}^{-2} \mathrm{~s}^{-1}\right) ; A\left(22.23 \mu \mathrm{mol} \mathrm{CO} \mathrm{Cm}^{-2} \mathrm{~s}^{-1}\right)$; carboxylation efficiency $A / C_{i}\left(0.098 \mu \mathrm{mol} \mathrm{CO} \mathrm{m}^{-2} \mathrm{~s}^{-1} / \mu \mathrm{mol} \mathrm{CO} \mathrm{mol}^{-1}\right)$; and $A / E \quad\left(3.12 \mu \mathrm{mol} \quad \mathrm{CO}_{2} \quad \mathrm{~m}^{-2} \mathrm{~s}^{-1} / \mathrm{mmol} \quad \mathrm{H}_{2} \mathrm{O} \quad \mathrm{m}^{-2} \mathrm{~s}^{-1}\right)$. Simultaneously in the same month, the lowest results were reported when plants were irrigated by the dripping system, despite the fact that they were submitted to the same $Q_{\text {leaf }}\left(1.397 \mu \mathrm{mol}\right.$ photons $\left.\mathrm{m}^{-2} \mathrm{~s}^{-1}\right)$; these results were the following: $E\left(1.07 \mathrm{mmol} \mathrm{H}_{2} \mathrm{O} \mathrm{m} \mathrm{m}^{-2} \mathrm{~s}^{-1}\right) ; g_{s}(0.02$ mol $\left.\mathrm{H}_{2} \mathrm{O} \mathrm{m}^{-2} \mathrm{~s}^{-1}\right) ; A\left(1.98 \mu \mathrm{mol} \mathrm{CO} \mathrm{CO}_{2} \mathrm{~m}^{-2} \mathrm{~s}^{-1}\right)$; carboxylation efficiency $A / C_{i}\left(0.009 \mu \mathrm{mol} \mathrm{CO} \mathrm{CO}^{-2} \mathrm{~s}^{-1} / \mu \mathrm{mol} \mathrm{CO} \mathrm{CO}^{-1}\right)$; and $A / E\left(1.84 \mu \mathrm{mol} \mathrm{CO} \mathrm{m}^{-2} \mathrm{~s}^{-1} / \mathrm{mmol} \mathrm{H}_{2} \mathrm{O} \mathrm{m}^{-2} \mathrm{~s}^{-1}\right)$. The inferior banana plant cooling caused by the dripping system, attested by the highest $T_{\text {leaf }}$ result $\left(40.44^{\circ} \mathrm{C}\right)$, jeopardized the enzymatic functions, as shown by the $A / C_{i}$ ratio, and promoted stomatal closure, which is proven by the lower $g_{s}$ results, despite the mild weather conditions of the aforementioned month.

The cultivars studied differed concerning $A$ at the 12 p.m. assessment time only when irrigated by the dripping system (Table 4). Additionally, $A$ varied for all irrigation systems in both cultivars in most of the months assessed. The cultivars exhibited the highest $A$ levels when irrigated with micro-sprinklers and lowest levels when irrigated by the dripping and by conventional under-tree sprinkling systems, respectively.

The results for 'Prata-Anã' irrigated with microsprinklers in the months of August and September 2010, at 12 p.m., estimated the same $Q_{\text {leaf }}(1,416.10$ and $1,442.80$ $\mu \mathrm{mol}$ photons $\left.\mathrm{m}^{-2} \mathrm{~s}^{-1}\right)$, however, the gas exchange did differ. $E$ (3.23 and $\left.5.33 \mathrm{mmol}_{2} \mathrm{O} \mathrm{m}^{-2} \mathrm{~s}^{-1}\right), A(8.35$ and $\left.19.19 \mu \mathrm{mol} \mathrm{CO} \mathrm{CO}_{2} \mathrm{~m}^{-1}\right)$, and $A / E\left(2.57\right.$ and $3.60 \mu \mathrm{mol} \mathrm{CO}_{2}$

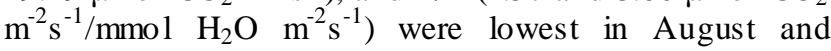
highest in September, respectively. This is an avid example of the response to stomatal closure, ascertained by the lower $g_{s}$ result $\left(0.12\right.$ and $0.33 \mathrm{~mol} \mathrm{H} \mathrm{H}_{2} \mathrm{O} \mathrm{m}^{-2} \mathrm{~s}^{-1}$, respectively), and by the change in the activity of the rubisco enzyme, attested by the lower $A / C_{i}$ ratio $(0.03$ and $0.09 \mu \mathrm{mol} \mathrm{CO} \mathrm{m}^{-2} \mathrm{~s}^{-1} / \mu \mathrm{mol} \mathrm{CO} \mathrm{Cmol}^{-1}$, respectively).

The behavior described above represents the response of the plant to the lower humidity in the month of August than in the month of September. Both months exhibited absence of rainfall but differed concerning relative humidity (lower than $40 \%$ ), which was the lowest reported in the whole experimentation period. Additionally, August 2010 recorded higher ambient temperature (maximum temperature close to $35^{\circ} \mathrm{C}$ ) and higher leaf temperature $\left(35.16^{\circ} \mathrm{C}\right)$ in comparison to September of that same year.

The photosynthesis rates registered at 2 p.m. were the same for both cultivars in most of the months, except in cases in which the plants were irrigated with microsprinklers (Table 5). 'Prata-Anã' exhibited higher $A$ in all the irrigation systems. The Banana plants presented variation in the level of $A$ when irrigation was conducted by the different systems in most months and the highest results were obtained when the plants were irrigated with the dripping system.

The Pome type banana plants, regardless of the irrigation system, at 2 p.m., always exhibited higher $T_{\text {leaf }}$, as well as higher $E$, a cooling mechanis m of the plant. However, as a sign of stomatal closure, we observed lower $g_{s}$ and reduction of $A$, even when submitted to high levels of $Q_{\text {leaf }}$ (Table 5). 'BRS Platina', in January 2010, irrigated by micro-sprinkling and conventional sprinkling, exposed to high and moderate radiation $\left(1,628 \mu \mathrm{mol}\right.$ photons $\mathrm{m}^{-2} \mathrm{~s}^{-1}$ and $782.40 \mu \mathrm{mol}$ photons $\mathrm{m}^{-2} \mathrm{~s}^{-1}$, respectively), exhibited the highest $T_{\text {leaf }}$ values reported for this experiment, $37.86^{\circ} \mathrm{C}$ and $40.02^{\circ} \mathrm{C}$, respectively. Meanwhile, the photosynthesis rates were similarly low, 5.78 and 6.96 $\mu \mathrm{mol} \mathrm{CO}_{2} \mathrm{~m}^{-2} \mathrm{~s}^{-1}$, respectively. 
Another example of the same cultivar irrigated with the dripping system and exposed to $Q_{\text {leaf }}$ high radiation levels $\left(1,415.75 \mu \mathrm{mol}\right.$ photons $\left.\mathrm{m}^{-2} \mathrm{~s}^{-1}\right)$ occurred at $2 \mathrm{p} . \mathrm{m}$. in October 2009. In these conditions, we obtained the highest $T_{\text {leaf }}$ of the entire experimentation period $\left(43.22^{\circ} \mathrm{C}\right)$; high levels of $E\left(5.17 \mathrm{mmol} \mathrm{H}_{2} \mathrm{O} \mathrm{m} \mathrm{m}^{-2} \mathrm{~s}^{-1}\right)$, serving as a compensatory cooling mechanism; and, consequently, reduced level of $A\left(6.53 \mu \mathrm{mol} \mathrm{CO}_{2} \mathrm{~m}^{-2} \mathrm{~s}^{-1}\right)$. This was a consequence of the jeopardized enzy matic system caused by the increase of temperature, which resulted in a low $A / E$ ratio. Donato et al. (2013), studying genomic groups and subgroups of banana plants, found that $A / E$ decreased as $T_{\text {leaf }}$ increased, for all the water depths varying from 25 to $125 \%$ of the crop evapotranspiration. The same authors concluded that when cultivated in regions and/or in periods of above-optimal temperatures, even when provided with adequate amount of water, the plants had their transpiration and photosynthes is jeopardized.

Thus, under stressful conditions, cultivation practices should prioritize hydric and thermal comfort. Therefore, defoliation, sprout thinning, pseudostem cutting, straw management, and dimensioned irrigation to fit the peaks of evapotranspiration are indispensable practices in high productivity banana crops. These techniques allow better plant cooling through the exchange of latent and sensible heat, promoted by the water sprayed in the leaves or pseudostem, as well as better crop ventilation. Furthermore, in the case of more demanding consumer markets, it is possible to adopt protected cultivation techniques, such as those used in the Canary Islands, Turkey, and Israel (Galán Saúco \& Damatto Junior, 2012).

The assessment conducted at 4 p.m. registered different photosynthetic rates for each cultivar in most of the months when irrigated by micro-sprinkling and dripping systems (Table 6). Results were higher for 'BRS Platina' and lower for 'Prata-Anã'.

Carboxylation efficiency of $\mathrm{CO}_{2}\left(A / C_{i}\right)$ is an efficiency measurement of the rubisco enzyme and its variation exhibits the change of the activity of this enzyme fro m carbo xylase to oxygenase.

The evaluated cultivars presented similar $A / C_{i}$ at all the assessment times in most of the months and in all of the irrigation systems, with the exception of assessments at 10 a.m., when we observed different $A / C_{i}$ for each cultivar in all of the irrigation systems in most of the months (Table 3); and for assessments at 12 p.m., in which we obtained significant variance of $A / C_{i}$ for each cultivar in most of the months only in plants irrigated with the dripping system (Table 4). Furthermore, the values were

\section{A}

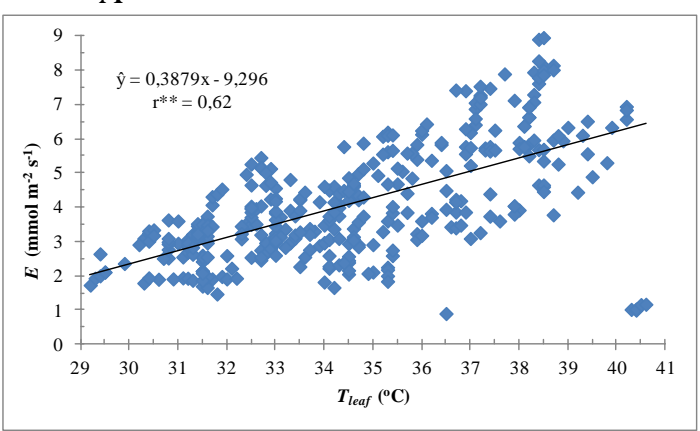

higher in the 'Prata-Anã' cultivar in both aforementioned assessment times in most cases.

Each cultivar presented different $A / C_{i}$ levels when cultivated in the different irrigation systems in most of the cases, with the exception of the 'Prata-Anã' cultivar at 8 a.m. and 'BRS Platina' at 4 p.m. However, it was impossible to establish an optimum variation standard. On the other hand, we observed that during the hottest time (2 p.m.), the highest $A / C_{i}$ level was reported in banana plants irrigated by dripping, which is probably due to the continuous supply of water during a long term.

Leaf water-use efficiency or instant water-use efficiency $(A / E)$ represents how much of carbon was fixed per a certain amount of transpired water. This variable can be expressed by the ratio between photosynthesis and transpiration. The values of $A / E$ found in the present study for Pome type banana plants cultivated in different irrigation systems were similar to those reported by Thomas et al. (1998) and Neves et al. (2002) and inferior to those observed by Melo et al. (2009).

The 'BRS Platina' and 'Prata-Anã' cultivars exhibited similar $A / E$ in most of the cases studied. Significant differences among cultivars regarding $A / E$ were observed at several assessment times, especially when irrigated with the micro-sprinkling system. This system probably provided lower stress conditions for the plants since the $A / E$ values were higher. Additionally, we could observe the superiority of the hybrid in relation to its parents.

Differences of $A / E$ in each of the irrigation systems for both cultivars in most of the months were observed at all the assessment times, with the exception of the last two; their values always being superior in the plants irrigated with micro-sprinklers. In the last assessment time, $A / E$ of the Pome type banana plants exhibited the highest percentage difference $(2,526 \%)$, observed at all of the assessment times, when considering all of the factors. 'BRS Platina' irrigated by dripping in June 2010 and by micro-sprinkling, in December 2009, displayed the lowest (0.71 $\left.\mu \mathrm{mol} \mathrm{CO}_{2} \mathrm{~m}^{-2} \mathrm{~s}^{-1} / \mathrm{mmol} \mathrm{H}_{2} \mathrm{O} \mathrm{m} \mathrm{m}^{-2} \mathrm{~s}^{-1}\right)$ and highest (18.65 $\mu \mathrm{mol} \mathrm{CO} \mathrm{Cm}_{2}^{-2} \mathrm{~s}^{-1} / \mathrm{mmol} \mathrm{H}_{2} \mathrm{O} \mathrm{m}^{-2} \mathrm{~s}^{-1}$ of $\mathrm{H}_{2} \mathrm{O}$ ) water use efficiency values, respectively.

The Pearson correlation test was applied to all the variables; however, positive, elevated, and significant correlations were found only between the transpiration rates $(E)$ and the leaf temperature $\left(T_{\text {leaf }}\right)$ (Figure 1). Furthermore, negative, elevated, and significant interactions were observed only between the instant use of water $(A / E)$ and leaf temperature $\left(T_{\text {leaf }}\right)$ (Figure 2), similar to what Donato et al. (2013) reported.

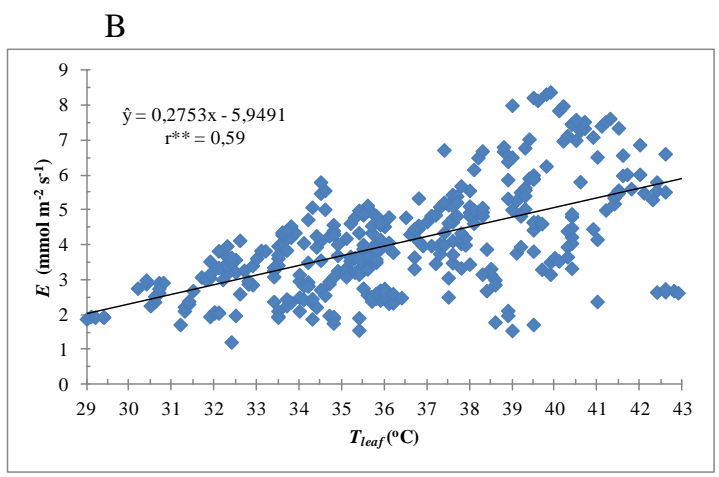


C

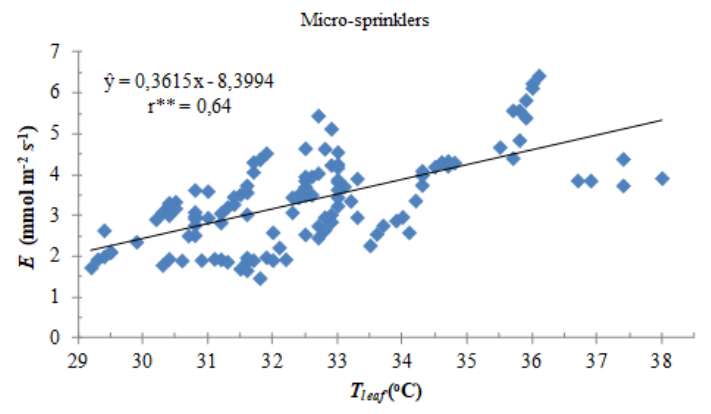

E

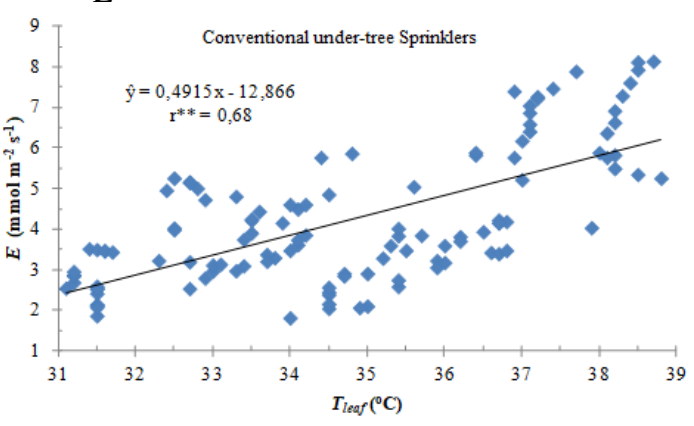

G

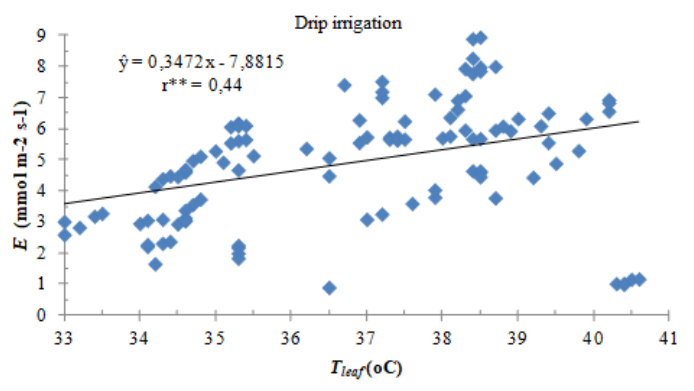

$\mathrm{D}$

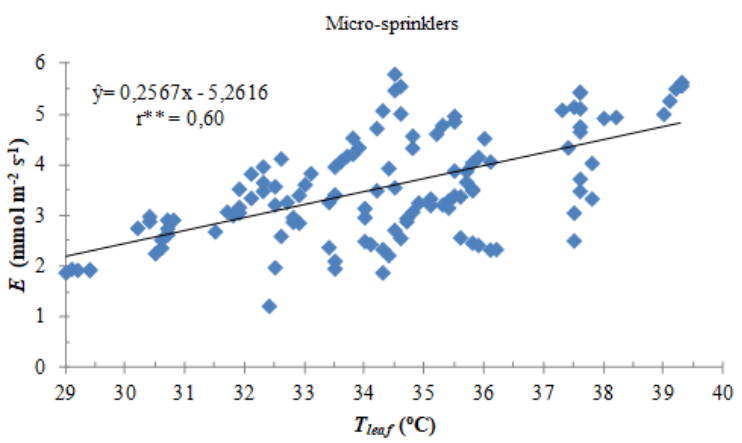

F

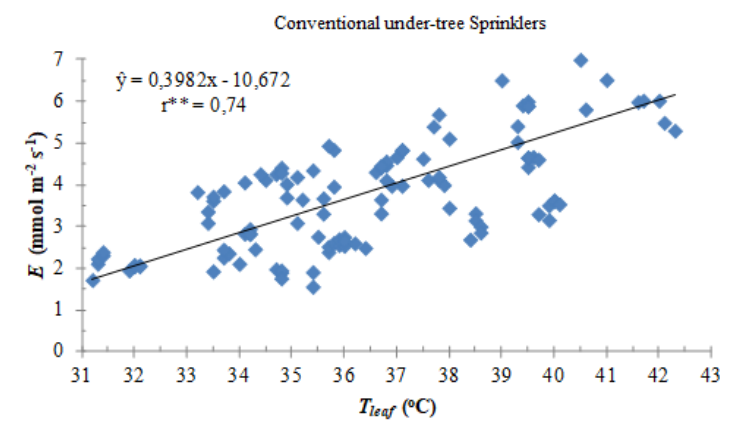

$\mathrm{H}$

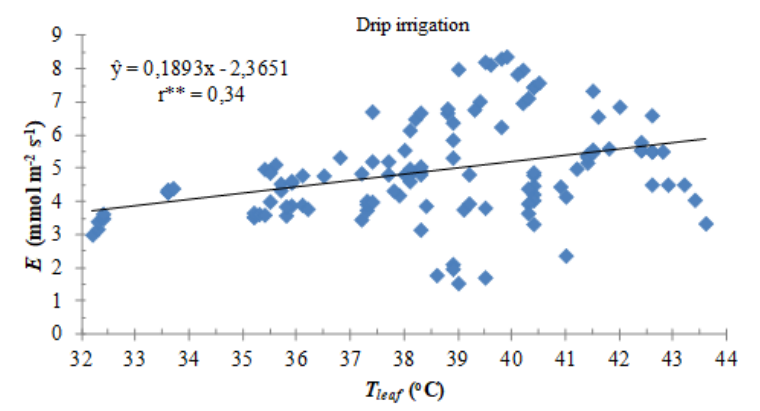

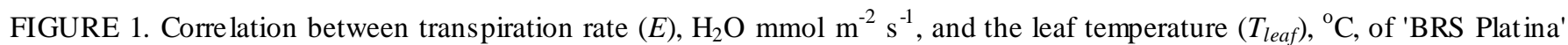
and 'Prata-Anã' banana plants at 10 a.m. (A) and at 12 p.m. (B); and in the various irrigation systems at 10 a.m. (C, E and G) and 12 p.m. (D, F and H) in Guanambi BA, 2009-2010.

The correlations between $E$ and $T_{\text {leaf }}$, considering all the factors, enabled the adjustment of a linear model, for the 10 a.m. assessment, which estimates an increase of 0.38 units of $E$ for each one-unit variation of $T_{\text {leaf }}$ (Figure 1A)

Linear models were also selected that describe the transpiration rate variation in relation to temperature for both cultivars in all irrigation systems at 10 a.m. (Figures $1 \mathrm{C}, \mathrm{E}$, and G) and at 12 p.m. (Figures 1D, F, and H). The largest variation ( 0.49 units) of $E$ for each increased unit of $T_{\text {leaf }}$ occurred when plants were irrigated by conventional under-tree sprinkling at 10 a.m. (Figure 6E). Furthermore, in the dripping irrigation system, we observed the highest trans piration levels.

Transpiration increased as leaf temperature increased, however, the photosynthesis and the stomatal conductance rates displayed different behavior, which contradicts logic. This proves that the alterations of photosynthesis rates in regions with stressful thermal conditions are more heavily influenced by enzymatic impairment, provoked by the temperature increase, than by stomatal closure. 

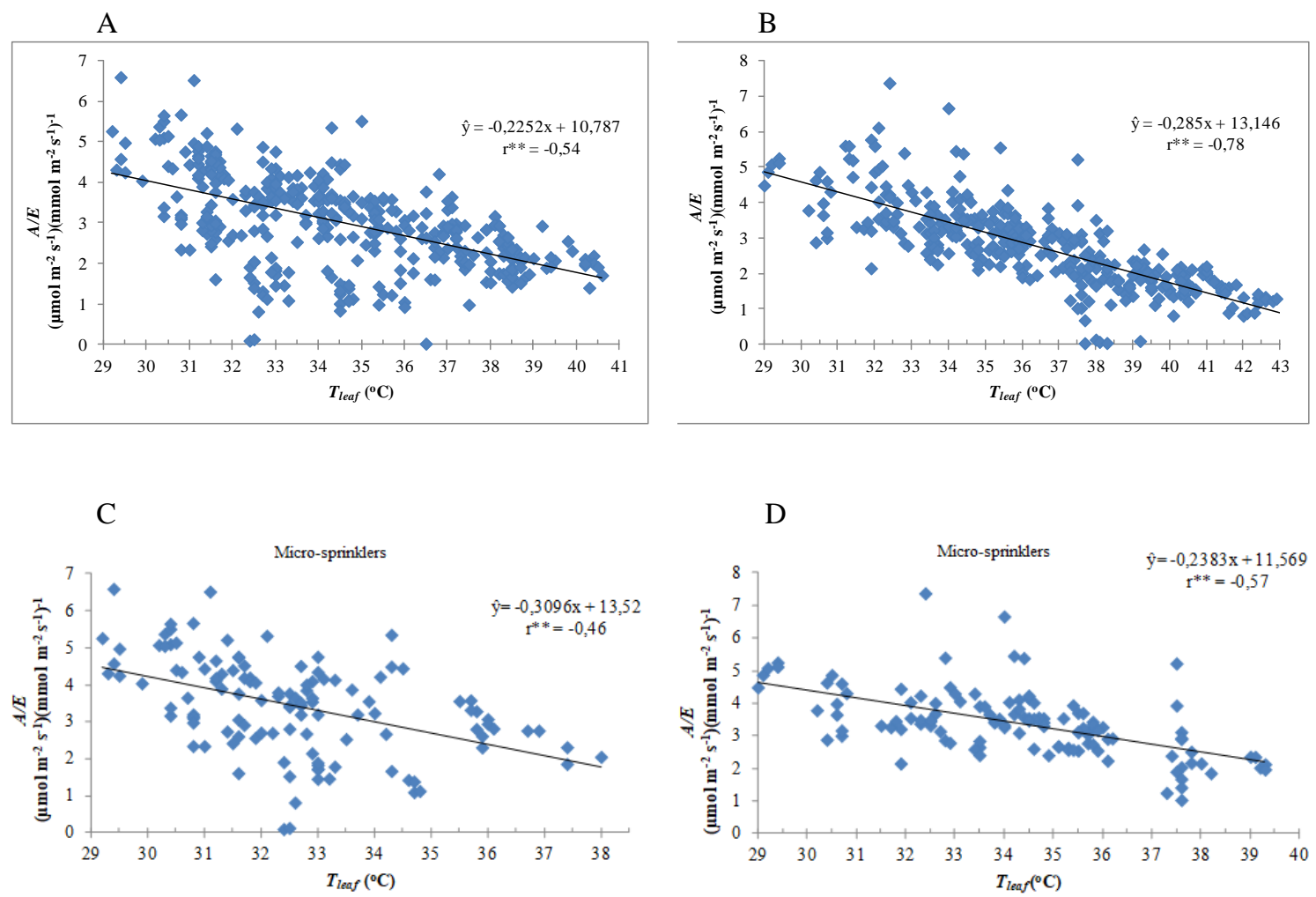

E
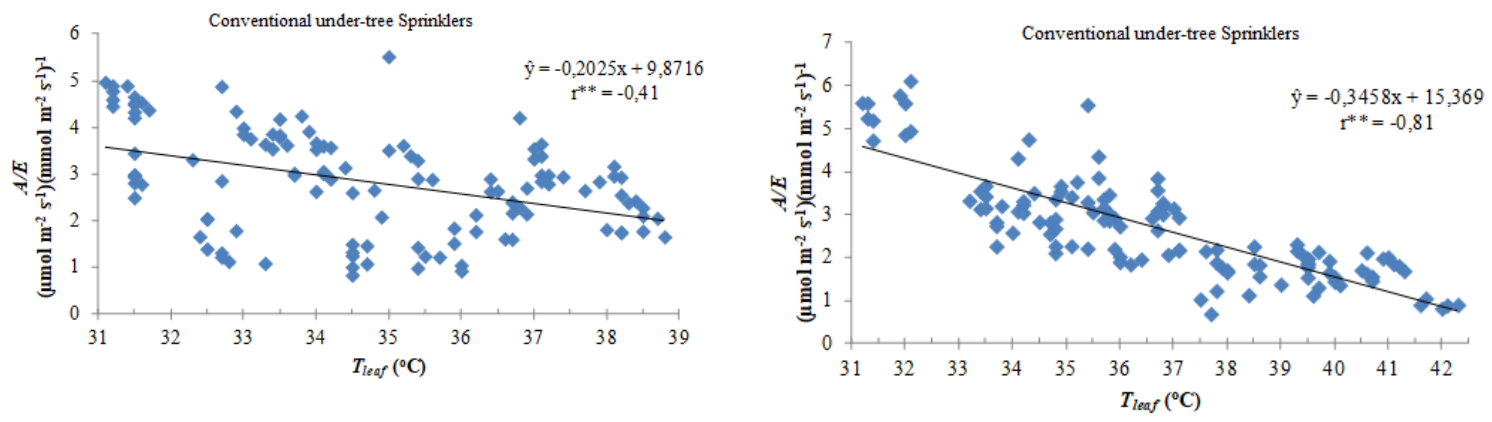

G

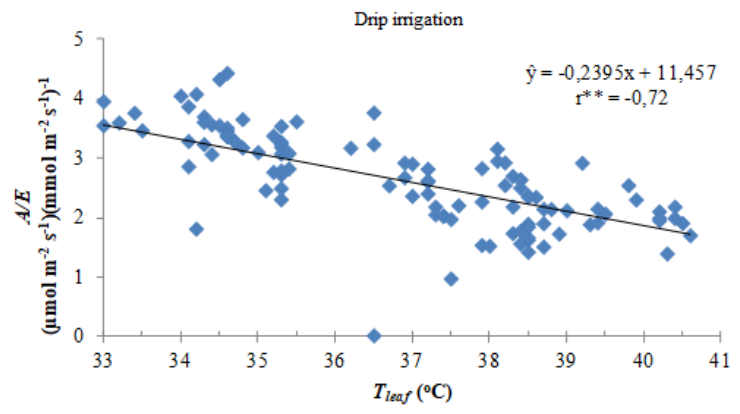

$\mathrm{H}$

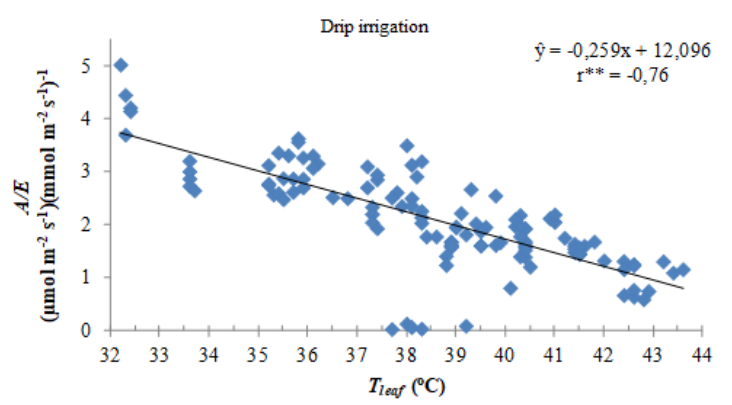

FIGURE 2. Correlation between the instant water use $(A / E), \mu \mathrm{mol} \mathrm{CO} 2 \mathrm{~m}^{-2} \mathrm{~s}^{-1} /\left(\mathrm{mmol} \mathrm{H}_{2} \mathrm{O} \mathrm{m} \mathrm{m}^{-2}\right)-1$, and the leaf temperature $\left(T_{\text {leaf }}\right),{ }^{\circ} \mathrm{C}$, of 'BRS Platina' and 'Prata-Anã' banana plants at 10 a.m. (A) and 12 p.m. (B); and the several irrigation systems at 10 a.m. (C, E and G) and 12 p.m. (D, F and H) in Guanambi BA, 2009-2010

The adjusted models, based on the correlation between $A / E$ and $T_{\text {leaf }}$, estimated a variation rate in $A / E$, which varies from the lowest value $(0.20$ units $)$ in conventional under-the-tree sprinkling at 10 a.m. (Figure 2E) to the highest ( 0.34 units) in conventional under-thetree sprinkling at 12 p.m. (Figure $2 \mathrm{~F}$ ), for the increase of each unit in $T_{\text {leaf }}$. The lowest $A / E$ was observed in the dripping irrigation system and the highest efficiency in the micro-sprinkling system. Thus, water-use efficiency decreased as the $T_{\text {leaf }}$ increased, which clearly demonstrates the effect of thermal stress.

\section{CONCLUS IONS}

Pome type banana plants display better strength and a larger number of hands when irrigated with microsprinklers and conventional under-tree sprinkling systems than when watered by the dripping irrigation system, regardless of the cultivar used, while yield was similar for all systems. Furthermore, when irrigated by dripping, the 
plants exhibited higher leaf temperature $\left(T_{\text {leaf }}\right)$, higher transpiration, and lower instant water use efficiency, while plants irrigated by micro-sprinkling displayed better water use efficiency.

The 'Prata-Anã' banana plant presented higher leaf area and a larger number of hands than 'BRS Platina', regardless of the irrigation system used.

The transpiration rates increased linearly as the leaf temperature increased, while the instant water use efficiency decreased linearly.

\section{REFERENCES}

Borges AL, Coelho EF, Costa EL, Teixeira AHC (2011) Irrigação e fertirrigação da bananeira. In: Souza VF, Marouelli WA, Coelho EF, Pinto JM, Coelho Filho MA (eds). Irrigação e fertirrigação em fruteiras e hortaliças. Brasília, DF, Embrapa Informação Tecnológica, p369-397.

Donato SLR, Silva SO, Lucca Filho OA, Lima MB, Domingues H, Alves JS (2006) Comportamento de cultivares e híbridos de bananeira (Musa spp.), em dois ciclos de produção no sudoeste da Bahia. Revista Brasileira de Fruticultura 28:139-144.

Donato SLR, Arantes AM, Silva SO, Cordeiro ZJM (2009) Comportamento fitotécnico da bananeira 'Prata-Anã' e de seus híbridos. Pesquis a Agropecuária Brasileira 44(12):1508-1515.

Donato SLR, Coelho EF, Marques PRR, Arantes AM, Santos MR, Oliveira PM (2013) Ecofisiologia e eficiência de uso da água em bananeira. In: Reunião Internacional da Associação para a Cooperação em Pesquisa e Desenvolvimento Integral das Musáceas (Bananas e Plátanos). Cruz das Almas, Embrapa Mandioca e Fruticultura, Proceedings... p58-72.

Galán Saúco V, Damatto Junior ER (2012) Cultivo de bananeira em a mbiente protegido. In: Chavarria G, Santos HP (eds). Fruticultura em a mbiente protegido. Brasília, Embrapa, p19-48.

Mahouachi J (2009) Changes in nutrient concentrations and leaf gas exchange parameters in banana plantlets under gradual soil mo is ture depletion. Scientia Horticulturae 120(4):460-466.

Marques PRR, Donato SLR, Pere ira MCT, Coelho EF, Arantes AM (2011) Características agronômicas de bananeiras tipo prata sob diferentes sistemas de irrigação. Pesquisa Agropecuária Brasileira 46(8):852-859.

Melo AS, Silva Júnior CD, Fernandes PD, Sobral LF, Brito MEB, Dantas JDM (2009) Alterações das características fisiológicas da bananeira sob condições de fertirrigação. Ciência Rural 39(3):733-741.

Melo AS, Fernandes PD, Sobral LF, Brito MEB, Dantas JDM (2010) Crescimento, produção de biomassa e eficiência fotossintética da bananeira sob fertirrigação com nitrogênio e potássio. Revista Ciência Agronômica 41(3):417-426.
Neves LLM, Siqueira DL, Cecon PR, Martinez CA, Salo mão LCC (2002) Crescimento, trocas gasos as e potencial osmótico da bananeira 'Prata', submetida a diferentes doses de sódio e cálcio em solução nutritiva. Revista Brasileira de Fruticultura 24(2):524-529.

Oliveira TK, Lessa LS, Silva SO, Oliveira JP (2008) Características agronômicas de genótipos de bananeira em três ciclos de produção em Rio Branco, AC. Pesquisa Agropecuária Brasileira 43(8):1003-1010.

Robinson JC, Galán Saúco V (2010) Bananas and platains. Oxford, CA B International. 2 ed. 311p. (Crop Production Science in Hort iculturae Series, 19).

Rodrigues MGV, Donato SLR, Lichtemberg LA, Dias MSC (2015) Imp lantação e manejo do bananal. Informe Agropecuário 36:27-44.

Sant'ana JAV, Coelho EF, Faria MA, Silva EL, Donato SLR (2012) Distribuição de raízes de bananeira no solo irrigado por diferentes sistemas de irrigação em condições semiáridas. Revista Brasileira de Fruticultura 34(1):124133.

Senevirathna AMWK, Stirling CM, Rodrigo VHL (2008) Acclimation of photosynthesis and growth of banana (Musa sp.) to natural shade in the humid tropics. Experimental Agriculture 44:301-312.

Silva Junior GSE, Morais, MB, Camara TR, Willadino L (2012) Crescimento de genótipos diploides de bananeira submetidos ao estresse salino. Revista Brasileira de Engenharia Agrícola e A mbiental 16:1145-1151.

Soto Ballestero M (2008) Bananos: técnicas de produción, poscosecha y comercialización. San José, Litografia e Imprensa LIL, 3 ed. 1 CD-ROM.

Taiz L, Zeiger E (2013) Fisiologia vegetal. Porto Alegre, Artmed, 5 ed. 954p.

Thomas DS, Turner DW, Eamus D (1998) Independent effects of the environment on the leaf gas exchange of three banana (Musa sp.) cultivares of different genomic constitution. Scientia Horticulturae 75:41-57.

Turner DW (2013) Crop physiology and cultural practices - a synergy in banana and plantain (Musa spp.). In: Symposium on Bananas and Plantains: Towards Sustainable Global Production and Improved Uses. Proceedings... p986.

Zucoloto M, Lima JSS, Coelho RI (2008) Modelo matemático para estimativa da área foliar total de bananeira 'Prata-Anã'. Revista Brasileira de Fruticultura 30:1152-1154. 